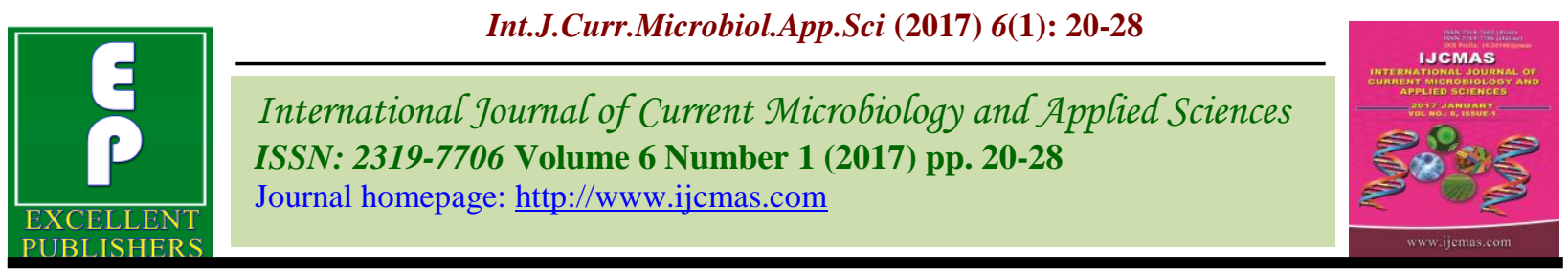

Original Research Article

http://dx.doi.org/10.20546/ijcmas.2017.601.003

\title{
Isolation, Identification and Optimization of Alkaline Amylase Production from Bacillus cereus Using Agro-Industrial Wastes
}

\author{
M. Krishma and S. Radhathirumalaiarasu* \\ Department of Microbiology, Standard Fireworks Rajaratnam College (Autonomous), \\ Sivakasi- 626 123, Tamilnadu, India \\ *Corresponding author
}

\begin{abstract}
A B S T R A C T
Keywords

Amylase,

B. cereus,

alkaline, wheat

bran, submerged

fermentation.

Article Info

Accepted:

09 December 2016

Available Online:

10 January 2017

Amylase with maximum activity at alkaline $\mathrm{pH}$ prefers most industrial applications. The present study investigate amylase production and optimization by bacterial strain isolated and identified from rice mill waste dumped soil. The potent isolate KR9 was identified based on biochemical characteristics and 16S rRNA gene analysis confirmed that this isolate belonged to the genus Bacillus and it was most closely related to B. cereus (99\% similarity). The selected isolate $B$. cereus $\mathrm{KR} 9$ was optimized for $\mathrm{pH}$, growth period and carbon and nitrogen sources. The highest activity of amylase was obtained at alkaline $\mathrm{pH}$ 10.0 after 48 hours $(225.2 \pm 0.63 \mathrm{U} / \mathrm{ml})$ incubation. Optimization experiment performed with synthetic medium showed starch and peptone as suitable carbon and nitrogen source for amylases production $(221 \pm 0.77 \mathrm{U} / \mathrm{ml})$. B. cereus KR9 was further evaluated for amylase production using Solid State Fermentation and Submerged Fermentation with wheat bran, rice straw, paddy straw and sugarcane bagasse. The maximum amylase production of $281.1 \pm 0.65 \mathrm{U} / \mathrm{ml}$ with specific activity of $1.11 \pm 0.01 \mathrm{U} / \mathrm{mg}$ was observed with wheat bran using Submerged State Fermentation. This work has impending utilizing of agro-industrial waste affords cost effective and ecofriendly method for amylase production.
\end{abstract}

\section{Introduction}

Agro-industrial wastes are mainly generated during the industrial food processing of agricultural products are rich in sugars, minerals and proteins. The increasing energy demand has been focused worldwide attention on the utilization of renewable agricultural and industrial wastes as their disposal poses environmental problems, if not properly managed or treated (Thangaratham and Manimegalai, 2014). The carbon sources, nutrients and moisture present in such wastes provides suitable conditions for the growth of microorganisms, and hence these wastes can be used as suitable source for the production of a variety of compounds which are of great value. The main products which can be produced are enzymes, ethanol, reducing sugars, protein etc. (Singh, 2014).

Starch degrading enzymes like amylase have received great deal of attention because of their perceived technological significance and economic benefits. Biosynthesis of amylases was performed on agro-industrial wastes and by-products such as starchy materials to solve pollution problems and obtain a low cost 
medium. The application of an amylase in industrial reactions depends on its unique characteristics, such as its action pattern, substrate specificity, major reaction products, optimal temperature and $\mathrm{pH}$ (Senthil Kumar et al., 2012). Among the bacterial sources Bacillus subtilis, Bacillus sterothermophilus, Bacillus amyloliquefaciens, Bacillus licheniformis, Bacillus acidocaldarius, Bifidobacterium bifidum and Bifidobacterium acerans are important species for amylase production (Abd-Elhalem et al., 2015).

To meet the demands of industries low cost medium were used for the production of amylases (Puri et al., 2013; Karri et al., 2014). However the selection of a particular strain is prerequisite for the commercially significant enzyme yield. Agro-industrial wastes are usually considered the best substrates for the solid state fermentation (SSF). On the other hand Amylase production by different organisms in submerged state fermentation has received more interest and is found to be costprohibitive because of high cost of process engineering. Hence this study was focused on the isolation and selection of particular strain having ability to produce amylase. Further both submerged fermentation $(\mathrm{SmF})$ and solid state fermentation (SSF) carried out to evaluate the amylase activity of the amylolytic bacteria using agro- industrial waste as a feed substrate.

\section{Materials and Methods}

\section{Isolation of amylase producing bacteria}

Soil samples were collected in containers under sterile conditions from different area (waste paper mill, Thiruthangal, Sivakasi and rice mill, Krishnan koil, Virudhunagar, Tamilnadu, India). The samples were then serially diluted with saline solution and an aliquot $(0.1 \mathrm{ml})$ from the dilution $10^{-4}$ to $10^{-7}$ was spread plated on starch agar plate $(1 \%$ w/v). After 24 hours incubation at $37{ }^{\circ} \mathrm{C}$ amylolytic bacteria formed clear halos with $0.1 \%$ iodine solution were identified as starch utilizing strains. The halo diameters of bacterial colonies were measured and the selected strains were further screened for amylase activity.

\section{Identification of Amylase producing bacteria}

Microscopic examination and biochemical characterization of the isolates were carried on the basis of characters given in Bergey's manual of Systematic Bacteriology (Bergey, 1957). Overnight culture (1.5ml) of selected isolates in Nutrient broth was centrifuged at $5000 \times \mathrm{g}$ for $10 \mathrm{~min}$ at room temperature. The cell pellet was used for extraction of total genomic DNA. For amplification of the 16s rDNA gene, universal primers F 27 (5-AGAGTTTGAT CMTGGC TCAG-3) and R1492 (5-TACGGYACCT TGTTACGACTT-3) were used (Macrogen, Korea). DNA sequence data sets were assembled using the Bioedit sequence alignment editor sotware, version 7.0 sequence similarity values were determined using the basic local alignment search tool (BLAST) of the National Centre of Biotechnology Information (NCBI).

\section{Enzyme production}

Amylase production was carried out using the Fermentation medium containing the soluble starch $(10 \mathrm{~g} / \mathrm{l})$, yeast extract $(20 \mathrm{~g} / \mathrm{l}), \mathrm{KH}_{2} \mathrm{PO}_{4}$ (0.10g), $\mathrm{CaCl}_{2}(0.10 \mathrm{~g} / \mathrm{l}), \mathrm{MgSO}_{4}(0.05 \mathrm{~g} / \mathrm{l})$, and $\mathrm{FeSO}_{4}(0.2 \mathrm{~g} / \mathrm{l})$. The $\mathrm{pH}$ of the medium was adjusted to $\mathrm{pH} 7$. The medium was sterilized and the overnight culture $(1 \% \mathrm{v} / \mathrm{v})$ was inoculated into fermentation medium.

\section{Effect of $\mathrm{pH}$ and incubation time}

The effect of different $\mathrm{pH}$ on amylase production was observed. The $\mathrm{pH}$ of the 
fermentation media was set from 6 to $11 \mathrm{pH}$. The medium was sterilized and the overnight culture $(1 \% \mathrm{v} / \mathrm{v})$ was inoculated into minimal medium. At different time interval (24-96 hours) the amylase production were analyzed.

\section{Carbon and Nitrogen sources}

The effect of different carbon and nitrogen sources on amylase production was observed in the fermentation media containing starch, glucose or sucrose as carbon and ammonium sulphate, peptone and casein as nitrogen source. The fermentation broth culture was incubated at $37^{\circ} \mathrm{C}$ for 48 hours. Later the supernatants obtained by centrifugation were analyzed for protein content and amylase activity.

\section{Production of amylase using Agro- industrial wastes}

Amylase production was carried out using the solid state fermentation medium taken in 100 $\mathrm{ml}$ Erlenmeyer flasks containing $5 \mathrm{~g}$ of the substrate (wheat bran, rice straw, paddy straw and sugarcane bagasse) impregnated with 10 $\mathrm{ml}$ of sterile liquid medium $(\mathrm{g} / \mathrm{l}):\left[\mathrm{KH}_{2} \mathrm{PO}_{4}-\right.$ $0.1 \mathrm{~g} / \mathrm{l}, \mathrm{NaCl}-0.25 \mathrm{~g} / \mathrm{l}, \mathrm{MgSO}_{4} .7 \mathrm{H}_{2} \mathrm{O}-0.01 \mathrm{~g} / \mathrm{l}$, $\mathrm{CaCl}_{2}$ 0.01g/l]. Submerged fermentation was carried out with $10 \mathrm{~g} / \mathrm{l}$ of substrate at optimum $\mathrm{pH}$. The flasks were autoclaved and inoculated with $(1 \mathrm{ml})$ of the prepared inoculum, thoroughly mixed and followed by incubation at $37^{\circ} \mathrm{C}$ on rotary shaker at $150 \mathrm{rpm}$ for 48 hours. After incubation the samples were aseptically withdrawn centrifuged at $10,000 \mathrm{rpm}$ for $10 \mathrm{~min}$ and supernatant, and assayed for protein content and amylase activity. All the experiments were carried out at least in duplicates.

\section{Analytical method}

\section{Amylase Assay}

Amylase activity was determined using soluble starch as a substrate. The reaction mixture containing $1 \mathrm{ml}$ of soluble starch $1 \%$ $(\mathrm{w} / \mathrm{v})$ in $0.1 \mathrm{M}$ phosphate buffer $(\mathrm{pH} 7)$ and $100 \mu \mathrm{l}$ of enzyme solution was incubated at $37^{\circ} \mathrm{C}$ for 15 minutes. The reaction was stopped by adding $1 \mathrm{ml}$ of 3,5-dinitrosalicylic (DNS) acid solution followed by heating in a boiling water bath for $5 \mathrm{~min}$ and cooling at room temperature. Absorbance change (OD) was measured spectrophotometrically at 540 $\mathrm{nm}$. Using Amylase assay procedure (U) $\alpha-$ amylase activity was defined as the amount of enzyme that releases $1 \mu \mathrm{mol}$ of reducing sugars as glucose per minute, under assay conditions of $\mathrm{pH} 7$ and incubation temperature of $37^{\circ} \mathrm{C}$ with phosphate buffer solution (Kaur et al., 2015). The estimation of protein in amylolytic bacteria was done by protein Lowry's method (Lowry et al., 1951).

\section{Results and Discussion}

\section{Isolation and Identification of amylolytic bacteria}

A total of 36 bacterial strains were isolated and screened based on zone of hydrolysis and amylase activity. A potential amylolytic bacterium was selected and identified as Bacillus cereus KR9. The sequencing and blast results of the $16 \mathrm{~S}$ rRNA gene of the isolate KR9 exhibit $99 \%$ similarity to Bacillus cereus thus confirming the results of biochemical analysis that it belongs to gram positive spore forming rod. The sequence has been deposited in GenBank under the accession no. KX082775.

\section{Optimization of pH and growth period}

The highest activity of amylase was obtained at alkaline $\mathrm{pH} 10.0(223 \pm 0.71 \mathrm{U} / \mathrm{ml})$ and above that $\mathrm{pH}$ there was decline in amylase activity. At neutral $\mathrm{pH}$, there were moderate activity and at acidic $\mathrm{pH}$ the enzyme activity was extremely low $(94.9 \pm 0.2 \mathrm{U} / \mathrm{ml})$ (Figure 1A). However the enzyme was active at both acidic and alkaline $\mathrm{pH}$ with broad $\mathrm{pH}$ range of 
6 to 11 . It also retained $77 \%$ of its activity at $\mathrm{pH}$ 11.Most of the earlier studies revealed an optimum $\mathrm{pH}$ range between 6.0 and 7.0 for the growth of bacterial strains and enzyme production (Singh et al., 2010; Saxena and Singh, 2011; Alariya et al., 2013). B. cereus strain isolated from Cuddalore harbour waters grew maximally in shake flask with highest Amylase activity at $\mathrm{pH} 8.0$ which was sustained even at pH 11.0 (Annamalai et al., 2011). Deb et al. 2013 obtained maximum amylase production after 48 hours of incubation in fermentation medium with initial $\mathrm{pH} 9$.

In the time course study, enzyme activity was detected in the culture supernatant from 24 to 96 hours. At the optimum $\mathrm{pH}$ the maximum amylase production was found after 48 hours $(225.2 \pm 0.63 \mathrm{U} / \mathrm{ml})$. After that, a significant decrease was observed which could be due to denaturation of enzyme as already observed in other studies (Singh et al., 2010) or to the presence of secondary metabolites produced at the end of the stationary phase and toxic for the microorganism, thus resulting in a lower yield of enzyme (Figure 1B). The bacterial strain Bacillus subtilis RSKK96 was shown to produce extracellular $\alpha$-amylase at $72 \mathrm{~h}$ with an optimum of $37^{\circ} \mathrm{C}$ (Akcan et al., 2011). The maximum activity of $\alpha$-amylase $(21.87$ IU/min) was recorded after 48 hours for Aspergillus niger NCIM 1054 with fruit waste medium (Sharanappa et al., 2011).

\section{Optimization of Carbon and Nitrogen source}

The amylase production by the selected bacterium was optimized by supplementing different synthetic carbon sources. Among these supplementation of starch brought the highest amylase production $(219 \pm 0.57 \mathrm{U} / \mathrm{ml})$ compared to other carbon sources at 48 hours incubation for Bacillus sp. (Figure 2A). However, increased amylase production was obtained using maltose as carbon source for Bacillus sp. B3 and peptone as nitrogen sources respectively when the strains were grown at $60^{\circ} \mathrm{C}$, and $\mathrm{pH} 6.5$ for 48 hours (Thippeswamy et al., 2006).

The amylase production by the selected bacterium was also optimized by supplementing different inorganic and inorganic nitrogen sources. Results obtained showed peptone brought the highest amylase production compared to other nitrogen sources at 48 hours incubation $(221 \pm 0.77$ $\mathrm{U} / \mathrm{ml}$ ) (Figure 2B). Similar results were reported for B. Thermooleovorans (Sivaramakrishnan et al., 2006). Singh et al., 2010 found that supplementation of different nitrogen sources such as casein hydrolysate, ammonium chloride, yeast extract and sodium nitrate showed decline in enzyme production. However, in submerged fermentation $(\mathrm{SmF})$ maximum amylase production was observed with yeast extract $(163 \pm 3.6 \mathrm{U} / \mathrm{ml})$ and ammonium sulphate $\quad(70 \pm 3.0 \mathrm{U} / \mathrm{ml})$ (Sivakumar et al., 2012).

\section{Production of amylase using Agro wastes}

Natural sources could serve as economical and readily available raw material for the production of valuable enzymes. Agricultural wastes are being used for liquid fermentation to reduce the cost of fermentation media.

Commercially most of the production of $\alpha$ amylases is carried out in submerged fermentation, but solid-state fermentation is being looked at as a potential tool for its production, especially applying agro industrial residues as substrate. The result showed that, in SSF among the three substrates tested addition of Wheat Bran as substrate showed highest enzyme production of $154.2 \pm 0.65 \mathrm{U} / \mathrm{ml}$ with specific activity of 0.29 $\pm 0.01 \mathrm{U} / \mathrm{mg}$ (Figure 3A). Deb et al., 2013 showed that the production of enzyme was 
highest when corn flour was used as carbon source. Whereas Singh et al., (2010) found that wheat bran as suitable source for improved amylase production.

In submerged fermentation, with wheat bran as substrate the strain Bacillus cereus KR9 showed highest production of $281.1 \pm 0.65$ $\mathrm{U} / \mathrm{ml}$ with specific activity of $1.11 \pm 0.01$ after 48 hours of incubation (Figure 3B). Akcan et al., (2011) found that maximum $\alpha$-amylase production $858.6 \pm 41.9 \mathrm{U} / \mathrm{mg}$ was obtained in a medium containing $0.5 \%$ cotton stalk in 72 hours with submerged fermentation for Bacillus subtilis RSKK96.

Submerged fermentation was carried out for the production of amylase was observed in the range of 0.045-1.35 U/ml (Parmar and Pandya, 2012). Maximum amylase activity (373.89 IU/ml) was obtained with rice bran at $\mathrm{pH} 7.0$ after incubation of 48 hours by Streptomyces MSC702 in submerged fermentation (Singh et al., 2012).

Fig.1 Effect of $\mathrm{pH}(\mathrm{A})$ and incubation period (B) on the production of amylase by B. cereus KR9.
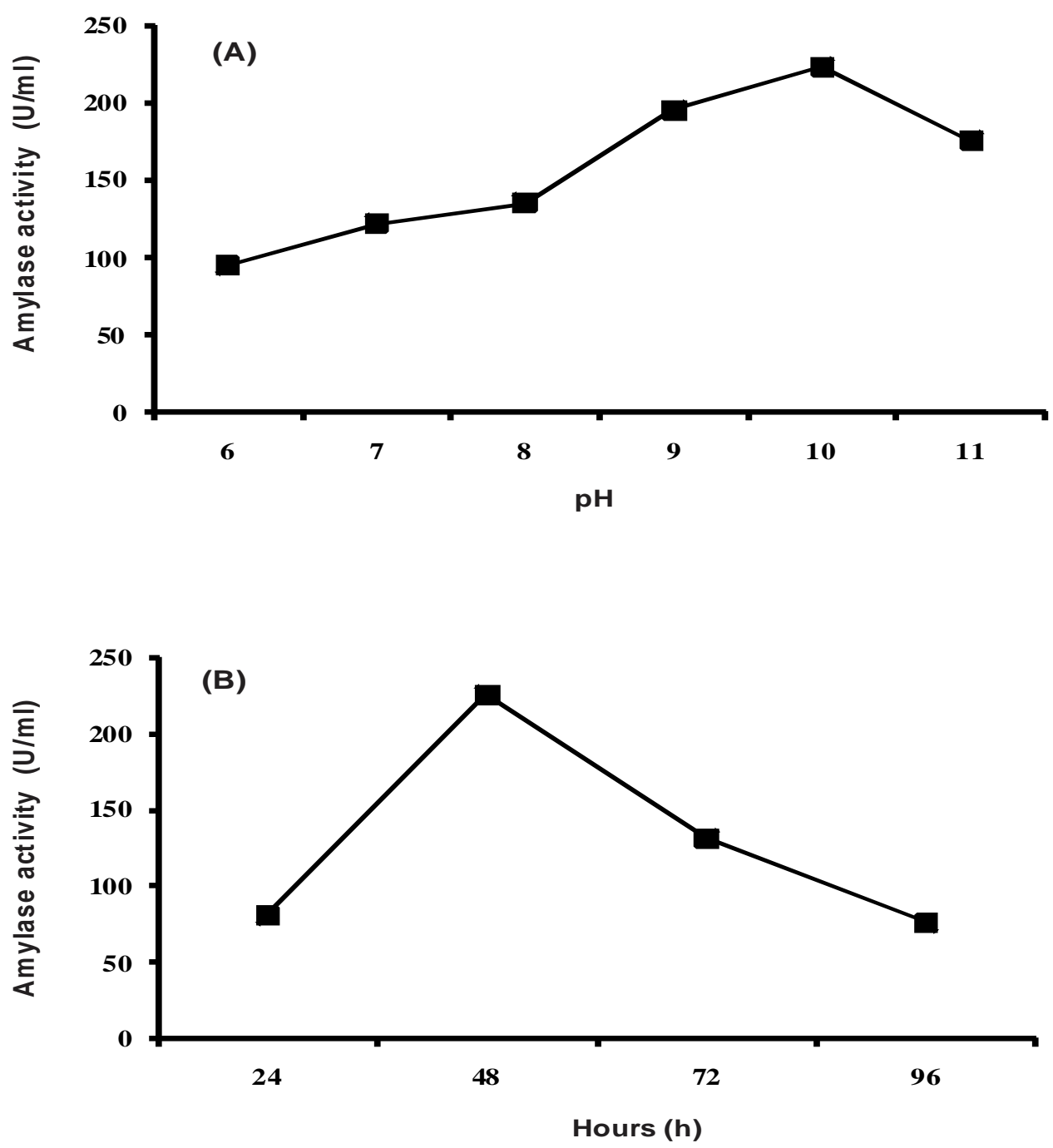
Fig.2 Effect of different Carbon (A) and nitrogen sources (B) on the production of amylase by B. cereus KR9.
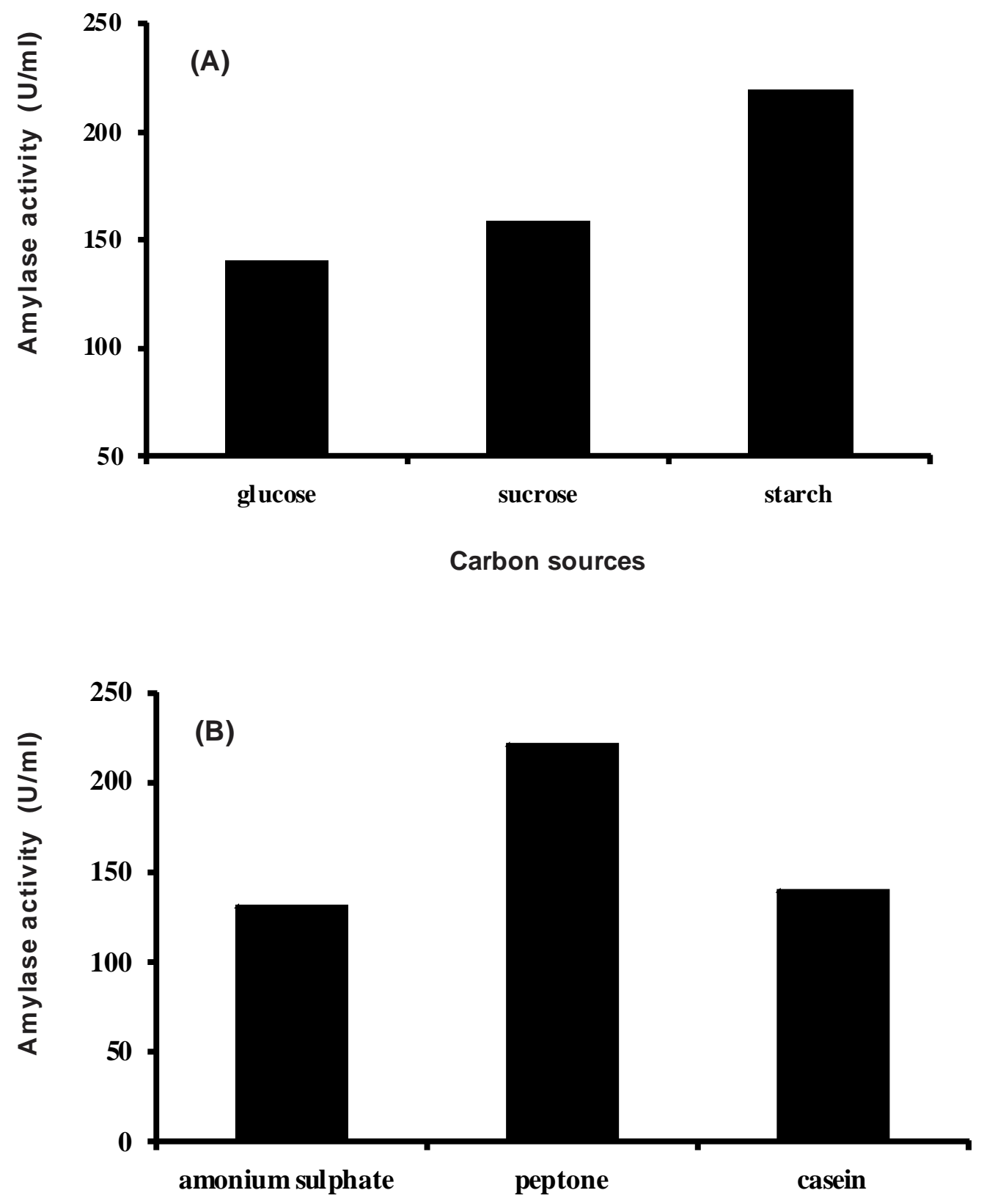

Nitrogen sources 
Fig.3 Production of amylase by B. cereus KR9 using agro-waste as substrate under (A) Solid state fermentation and (B) Submerged fermentation.
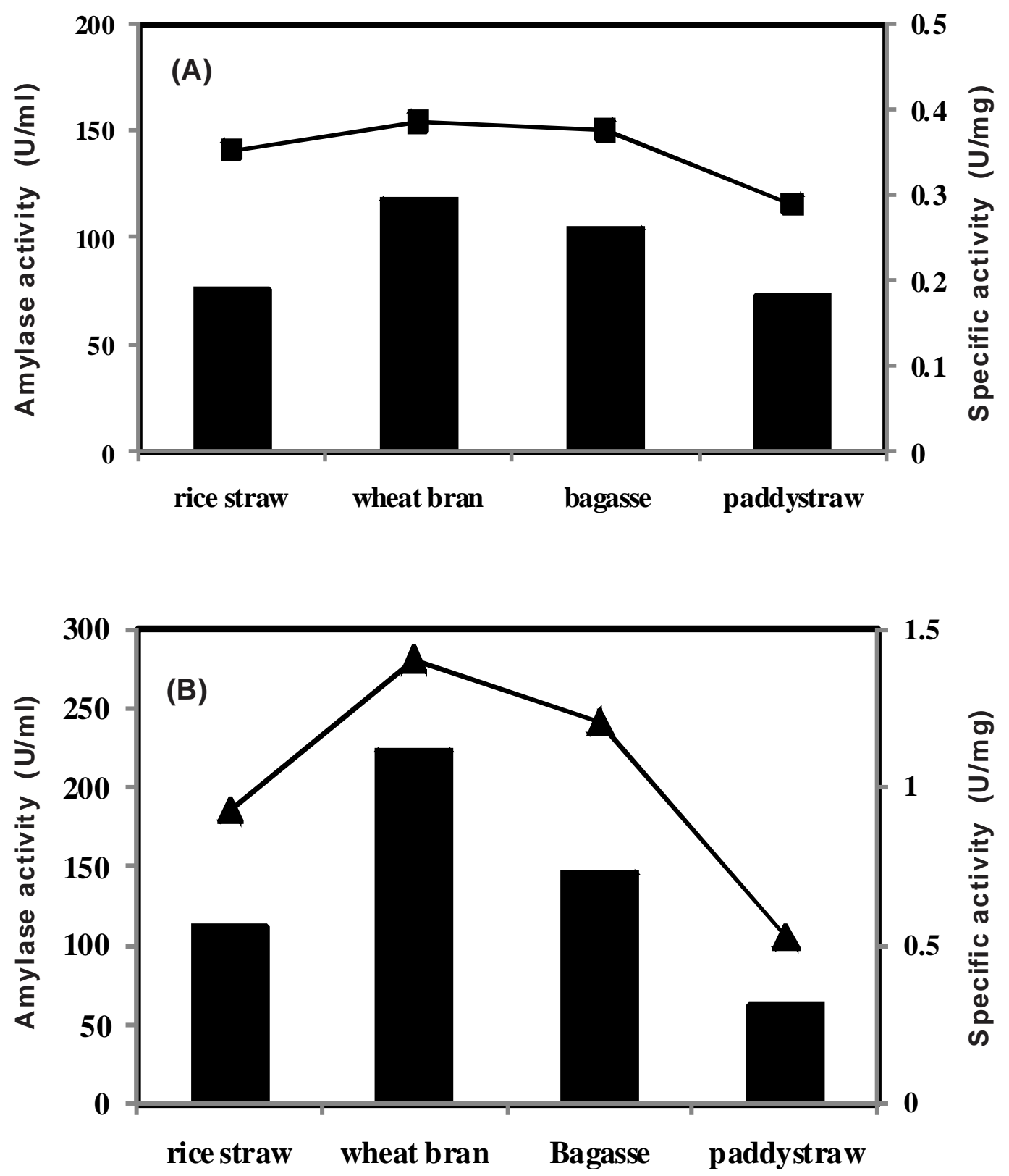

Agro-industrial waste

It was investigated that productive medium supplemented with $2 \%$ potato starchy waste as a low price substrate could be more favorable than basal medium containing $1 \%$ starch for amylases production in submerged fermentation, as it increased $\alpha, \beta$ and $\gamma$ amylase activity by 1.98, 7.69 and 12-fold than that produced in basal medium (AbdElhalem et al., 2015). 
In conclusion, this study was focused optimization of amylase production by $B$. cereus KR9 in both submerged fermentation (SmF) and solid state fermentation (SSF) using agro industrial waste. The optimum activity of the enzyme was obtained at alkaline pH 10.0 after 48 hours of incubation. Among the synthetic media for carbon and nitrogen sources tested supplementation of starch and peptone brought the highest amylase production $(215-221 \mathrm{U} / \mathrm{ml})$. Using agro wastes both in solid-state and submerged fermentation, addition of Wheat Bran as substrate showed the maximum production (154 -281 U/ml). However submerged fermentation showed maximum amylase production and considered to be suitable method for bacterial amylase production and it thus allowing a cheaper alternative substrate to obtain amylolytic enzymes.

\section{Acknowledgement}

We thank Management of the Standard Fireworks Rajaratnam College for women, Sivakasi for the facilities provided to make this work possible.

\section{References}

Abd-Elhalem, M. El-Sawy, B.T., Gamal, R.F. and Abou-Taleb, K.A. 2015. Production of amylases from Bacillus Amyloliquefaciens under submerged fermentation using some agroindustrial by-products. Ann. Agric. Sci., 3(4):110:115.

Akcan, N., Uyar, F. and Guven, A. 2011. Alpha-Amylase Production by Bacillus subtilis RSKK96 in Submerged Cultivation. Kafkas. Univ. Vet. Fak. Derg., 17-22.

Annamalai, N., Thavasi, R., Vijayalakshmi, S. and Balasubramanian, T. 2011. Extraction, Purification and Characterization of Thermostable,
Alkaline Tolerant a-Amylase from Bacillus cereus. Indian J. Microbiol., 51(4):424-429.

Alariya, S., Sonia Sethi, S., Gupta, S. and LalGupta, B. 2013. Amylase activity of a starch degrading bacteria isolated from soil. Arch. Appl. Sci. Res., 5(1): $15-24$.

Bergey, D. 1957. Manual of Determinative Bacteriology, American Society for Microbiology, Williams \& Wilkins Co. Publishers, Baltimore, USA. 1957. VIII Editions.

Deb, P., Talukdar, S.A., Mohsina, K., Sarker, P.K. and Abusayem, S.M. 2013. Production and partial characterization of extracellular amylase enzyme from Bacillus amyloliquefaciens, P-001. 2: 154.

Karri, S., Talla, S.G., Renuka and Dholpuri, S. 2014. Screening and production optimisation of alpha amylase from Aspergillus strains by using solid state fermentation. Int. J. Curr. Microbiol. App. Sci., 3(4): 623-631.

Kaur, P.S., Kaur, S., Kaur, H., Sharma, A., Raj, P. and Panwar, S. 2015. Solid Substrate Fermentation using Agro Industrial Waste: New Approach for Amylase Production by Bacillus licheniformis. Int. J. Curr. Microbiol. App. Sci., 4(12): 712-717.

Lowry, O.H., Rosebrough, N.J., Farr, A.J. amd Ramdall, R.J. 1951. Protein measurement with folin phenol reagent. J. Biol. Chem., 193: 265-275.

Parmar, D. and Pandya, A. 2012. Characterization of Amylase Producing Bacterial Isolates. Environ. Pharmacol. Life Sci., 1(6): 42 - 47.

Puri, S., Arora, M. and Sarao, L. 2013. Production and optimization of amylase and glucoamylase using Aspergillus oryzae under solid state fermentation. Int. J. Res. Pure Appl. Microbiol., 3(3): 83-88. 
Saxena, R. and Singh, R. 2011. Amylase production by solid-state fermentation of agro- industrial wastes using Bacillus sp. Braz. J. Mic.biol., 1(3): 1517-8382.

Senthilkumar, P.K., Uma, C. and Saranraj, P. 2012. Amylase Production by Bacillus sp. Using Cassava as Substrate. Int. J. Pharma. Biol. Arch., 3(2): 300-306.

Sharanappa, A., Wani, K.S., Patil, P. 2011. Bio processing of Food Industrial Waste For $\alpha$-Amylase production by solid state fermentation. Int. J. Biotechnol. Res., 2(4): 473-480.

Singh, R.K., Mishra, S.K. and Kumar, N. 2010. Optimization of $\alpha$-amylase production on agriculture byproduct by Bacillus cereus MTCC 1305 using solid state fermentation. Res. J. Pharma. Bio. Che. Sci., 1(4) 867-874.

Singh, R., Kapoor, V., and Kumar, V. 2012. Utilization of Agro-industrial Wastes for the Simultaneous Production of Amylase and Xylanase by Thermophilic Actinomycetes. Braz. J. Microbiol., 43(4): 1545-1552.

Singh, S. 2014. Production and characterization of industrially important amylase enzyme by
Aspergillus niger using different combination of starch waste as substrate. Int. J. Chemi. Pharma. Sci., $5(2)$.

Sivakumar, T., Shankar, T., Vijayabaskar, P., Muthukumar, J. and Nagendrakannan, E. 2012. Amylase Production Using Bacillus cereus Isolated from a Vermicompost Site. Int. J. Microbiol. Res., 3(2): 117-123.

Sivaramakrishnan, S.D., Gangadharan, K. M.C. and Pandey, R.S.A. 2006. $\alpha-$ Amylases from Microbial Sources - An Overview on Recent Developments. Food. Technol. Biotechnol., 44 (2): 173184.

Thangaratham, T. and Manimegalai, G. 2014. Optimization and Production of Pectinase Using Agro Waste by Solid State and Submerged Fermentation. Int. J. Curr. Microbiol. App. Sci., 3(9): 357-365.

Thippeswamy, S., Girigowda, K. and Mulimani, V.H. 2006. Isolation and Identification of $\alpha$-amylase producing Bacillus sp. from dhal industry waste. Indian J. Biochem. Biophy., 43: 295298.

\section{How to cite this article:}

Krishma, M. and Radhathirumalaiarasu, S. 2017. Isolation, Identification and Optimization of Alkaline Amylase Production from Bacillus cereus Using Agro-Industrial Wastes. Int.J.Curr.Microbiol.App.Sci. 6(1): 20-28. doi: http://dx.doi.org/10.20546/ijcmas.2017.601.003 